\title{
Urban hydrology in mountainous middle eastern cities
}

\author{
T. Grodek ${ }^{1}$, J. Lange ${ }^{2}$, J. Lekach ${ }^{1}$, and S. Husary ${ }^{3, *}$ \\ ${ }^{1}$ Geography Department, The Hebrew University of Jerusalem, Mt. Scopus, Jerusalem, 91905, Israel \\ ${ }^{2}$ Institute of Hydrology, University of Freiburg, Fahnenbergplatz, 79098 Freiburg, Germany \\ ${ }^{3}$ Palestinian Hydrology Group, P.O. Box 565, Ramallah, Palestinian National Authority \\ *now at: Welfare Association, Al Nahda Square, Canada St., Ramallah, Palestinian National Authority
}

Received: 9 August 2010 - Published in Hydrol. Earth Syst. Sci. Discuss.: 27 September 2010

Revised: 17 February 2011 - Accepted: 6 March 2011 - Published: 17 March 2011

\begin{abstract}
The Mediterranean climate together with the type of urban setting found in mountainous Middle Eastern cities generate much lower runoff yields than previously reported and than usually estimated for urban design. In fact, a close analysis shows that most of the rainwater remains within the cities as a possible source for urban groundwater recharge. The present study examined two locales - Ramallah, an old traditional Palestinian Arab town, and Modiin, a new township in Israel - both situated on the karstic Yarkon Taninim aquifer. This aquifer supplies the only high-quality drinking water in the region (one quarter of the Israeli-Palestinian water demand), which is characterized by dense populations and limited water resources.

This paper provides the first measured information on the hydrological effects of urbanization in the area. It was found that the shift of the mountainous natural steep slopes into a series of closed-terraces with homes and gardens create areas that are disconnected from the urban runoff response. Roofs drained into the attached gardens create favorable recharge units. Mainly low-gradient roads became the principal source for urban runoff already following 1-4 $\mathrm{mm}$ of rainfall. Parallel roads converted single peak hydrographs towards multi-peak runoff responses, increasing flow duration and reducing peak discharges. The remaining urban area (public parks, natural areas, etc.) generated runoff only as a result of high-magnitude rainstorms. All of the above conditions limited urban runoff coefficients to an upper boundary of only 35\% and 30\% (Ramallah and Modiin, respectively). During extreme rainstorms (above $100 \mathrm{~mm}$ ) similar runoff coefficients were measured in urban and natural catchments as a result of the limited areas contributing to runoff in the urban areas, while natural terrain does not have these artificial limits. Hence, the effects of urbanization decrease with
\end{abstract}

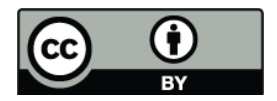

Correspondence to: T. Grodek (tamir.grodek@huji.ac.il) event magnitude and there is significant potential for urban groundwater recharge. However, frequent low-magnitude rainstorms often generate highly polluted stormwater in urban sewer systems and this water should only be used with great caution.

\section{Introduction}

Urban hydrology is ambiguous and depends on the combined effect of local climate and urban characteristics (Trowsdale and Lerner, 2007). Impervious surfaces (roads, parking lots and roofs) control urban stormwater and cause: (i) an increase in peak discharges and volumes (e.g., Dunne and Leopold, 1978; Cheng and Wang, 2002) that in turn increases flooding and erosion risks compared to pre-urbanization hydrology (e.g., Wolman and Schick, 1967; Trimble, 1997); and (ii) deterioration of the water quality by pollution from various sources (Smullen et al., 1999; Lee and Bang, 2000; Gnecco et al., 2005; US-NRC, 2008; Piguet et al., 2008). Worldwide water crises brought urban planners to adopt "Best Management Practices" (BMP) that prevent urban flooding and minimize stormwater pollution for further usage (e.g. Ashley et al., 2007; US-EPA, 1999, 2002; Martin et al., 2007).

In urban catchments, roads are primary runoff generators (Ramier et al., 2006). They replace natural drainage systems with relatively high runoff coefficients, limited flow capacity and higher drainage densities, contrary to natural catchments. This presumably results in increased runoff. However, some studies suggest that roads, roofs and other paved surfaces may absorb and evaporate significant amounts of rainwater (Hollis and Ovenden, 1988; Ramier et al., 2004, 2006; Ragab et al., 2003a,b). For example, in the hyperarid town of Elat, Israel, roads and parking lots were found to retain most of the rainwater (Grodek et al., 2000). In a coastal Mediterranean town with a large urban area no changes in

Published by Copernicus Publications on behalf of the European Geosciences Union. 
runoff peaks and volumes were detected over three decades (Garti et al., 1993). Moreover, polluted rainwater (Garnaud et al., 1999) and urban pollution accumulated on the road network becomes a primary source for urban stormwater pollution, mainly during first flush events (Lee et al., 2002, 2003; Mangani et al., 2005; Soller et al., 2005; Aryal et al., 2006; $\mathrm{Li}$ et al., 2007). The impact on groundwater recharge was found to be inconsistent: Kondoh and Nishiyama (2000) described limited aquifer recharge, while others showed rising groundwater levels beneath a city (Lerner, 1990). Deteriorated groundwater quality following sewer leakage (Rutsch et al., 2006) and other sources (e.g. extensive irrigation and sewage leakage) have become a widespread problem.

The population growth in Israel and the Palestinian territories (the West Bank and Gaza), from 2M in 1950 to $11 \mathrm{M}$ today, created tremendous pressure on the region's limited water resources (Feitelson and Haddad, 2000; Mizyed, 2000; Hassan et al., 2010a). The Coastal Aquifer along the Mediterranean shore is heavily populated $(70 \%$ of the area) and polluted (Graber et al., 2008). The less-populated Yarkon-Taninim mountainous karstic aquifer (Weinberger et al., 1994) still supplies relatively high-quality water, but in recent years aquifer levels have decreased and water quality deteriorated. Due to its karstic nature this deeper limestone aquifer is especially prone to contamination. Yet, to date for the cities located above this aquifer, only limited hydrological and potential pollution data is available for the town of Ramallah (Hassan et al., 2010b) while in Modiin such data simply does not exist. Without such data the results of urban runoff models (e.g., Bedient and Huber, 1992; Maidment, 1993; Zoppou, 2001) largely depend on crude assumptions without the necessary justification.

This study examines and compares the hydrological characteristics of two different Mediterranean towns: (a) Ramallah (West Bank, Palestinian territories), an old, traditional Arab town, located on the top of the Judean Mountains, and (b) Modiin (Israel) a new township built at the mountains foothills (Fig. 1). Different urban settings and designs are analyzed together with their impacts on urban stormwater generation. As such a comparison is made between a traditional and a new town, it will provide guidelines towards sustainable urban water planning in this thirsty region.

\section{Study area}

The region is characterized by a Mediterranean climate: (i) November-March winter-rains (above $85 \%$ of the mean annual rain) and (ii) hot-dry summers, May-September (Table 1). During winter, the eastern Mediterranean low pressure systems (e.g., Goldreich and Ronen, 2003) are responsible of about $95 \%$ of the rainfall (Sharon and Kutiel, 1986). In rare synoptic conditions, the Red Sea Trough generates short-duration rain bursts of high intensities (Dayan et al., 2001). Mean annual precipitation is $550 \mathrm{~mm}$ with a range

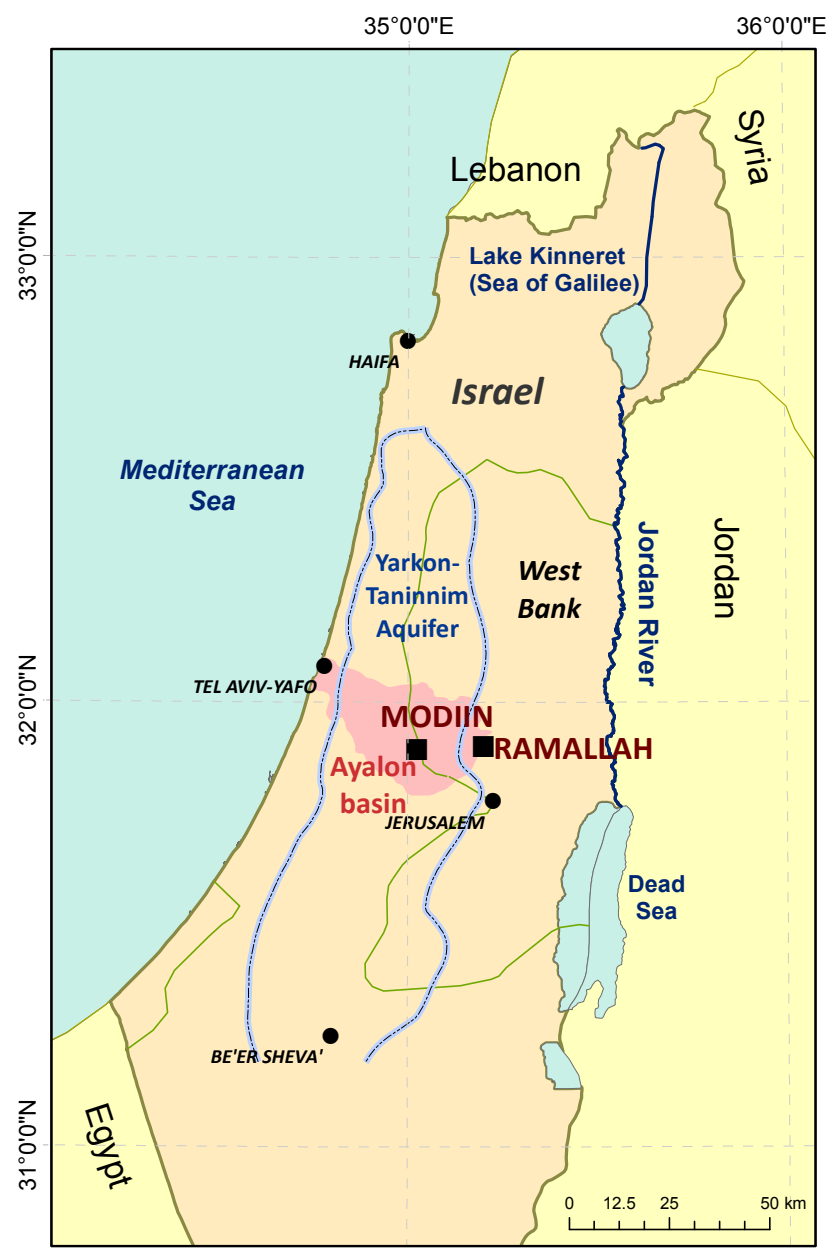

Fig. 1. Location map: the towns of Ramallah and Modiin within the Ayalon basin.

of 240-1200 mm (Morin et al., 1994). Most of the precipitation (80\%) occurs at low intensities (under $6 \mathrm{~mm} \mathrm{~h}^{-1}$ ) and only $1 \%$ falls with intensities exceeding $50 \mathrm{~mm} \mathrm{~h}^{-1}$ (Sharon and Kutiel, 1986). A single rainstorm may last from a few hours up to several days, characterized by several separate rain spells (minutes to hours) interrupted by dry intervals, which can last for several hours. The geology consist of carbonate limestone, dolomite and marl from the Cenomanian-Turonian period. In the foothills close to Modiin, Cenomanian-Touronian carbonates alternate with less permeable chalks and marls from the Senonoian period, partly covered by Calcrete crusts (Nari). Two types of soils dominate in the area: (i) Brown Rendzinas, shallow with a clay-loam texture; and (ii) reddish Terra Rossa of a typical clay-silt texture. The soils show high contents of organic matter (2-8\%), coarse texture and structure, which makes them susceptible to erosion. The study area encompasses two towns, Ramallah and Modiin, situated on the Judean Mountains, Nahal Ayalon Basin (Fig. 1): (a) Ramallah, located $10 \mathrm{~km}$ west of Jerusalem at altitudes of 
Table 1. Average climate data in the Ayalon basin. Note zero precipitation between May-September (Meteorological Service, Beit-Dagan station).

\begin{tabular}{lrrrrrrrrrrrr}
\hline Month & Jan & Feb & Mar & Apr & May & June & July & Aug & Sep & Oct & Nov & Dec \\
\hline Evaporation, mm/month & 59 & 64 & 130 & 162 & 189 & 213 & 220 & 208 & 171 & 130 & 84 & 62 \\
Temperature max ${ }^{\circ} \mathrm{C}$ & 17.8 & 18.1 & 20.1 & 24.5 & 27 & 29.2 & 30.8 & 31.2 & 30.4 & 28.3 & 24.1 & 19.7 \\
Temperature min ${ }^{\circ} \mathrm{C}$ & 7.2 & 7.1 & 8.8 & 11.5 & 14.6 & 17.9 & 20.6 & 21.2 & 19.4 & 16 & 11.8 & 8.6 \\
Rain, mm & 140 & 97 & 66 & 18 & 2 & 0 & 0 & 0 & 0.4 & 20 & 76 & 130 \\
Rain days & 10.1 & 8.6 & 6.5 & 2.3 & 0.5 & 0 & 0 & 0 & 0.2 & 2.3 & 5.8 & 8.9 \\
\hline
\end{tabular}

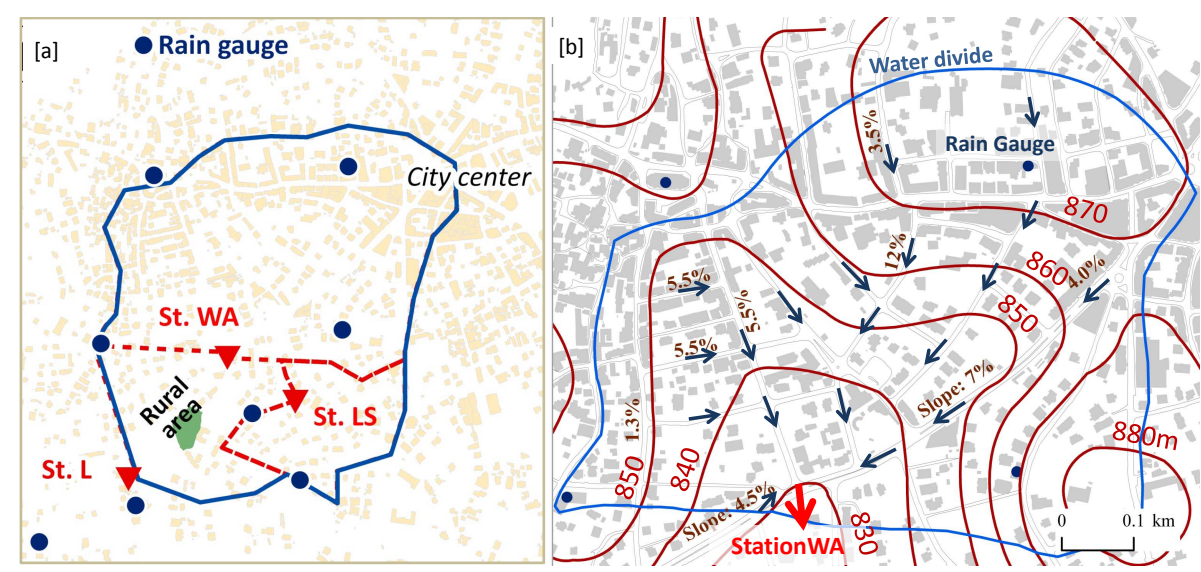

Fig. 2. (a) Ramallah city core and the investigated basins; (b) zoom into the sub basin and the hydrometric station WA. Road slopes (\%) and urban runoff flow-lines are indicated (blue arrows). Roads following the pre-urbanization topography.

750-850 $\mathrm{m}$ a.s.1. straddles the main north-south water divide. At the water divide topography is relatively flat, but nearby it changes steeply to westward and eastward facing slopes of up to $30 \%$. (b) Modiin is located $15 \mathrm{~km}$ west of Ramallah at the mountains foothill at altitudes of 200-300 $\mathrm{m}$ a.s.l. The gentle topography is less than $2 \%$ while the local relief is dominated by a series of rounded hills, about $20-40 \mathrm{~m}$ high, with slopes of $10 \%$. The local topography in both towns is characterized by agricultural terraces, some abandoned and some still in use. Non-terraced areas usually include bare rocks with only patches of soils. The shallow soils are characterized by a xeric moisture regime. During low-moderate rainstorms, overland flow remains within the leveled topography of the terraces and infiltrates into deeper soils. Only high magnitude rainstorms generate runoff (Lange et al., 2003).

Ramallah (Fig. 2) is a traditional Arab town built around an old quarter, which is the center for daily life and small commercial businesses. In historic times a small spring served as the main water supply. Today about $19 \%$ of the houses are connected to actively operated cisterns for drinking and irrigation in addition to the conventional water supply. Both modern and traditional houses are found around the city core. These areas also contain rural parts consisting of natural landscape and cultivated terraces, mainly on the western side of the city. In contrast, Modiin, founded in 1990, is the most rigidly planned town in Israel (Table 2, Fig. 3). Planning principles included the following: (i) steep slopes were altered into a series of low-gradient roads following the contour lines and terraces were used to build residential neighborhoods; and (ii) the main natural valleys were filled and leveled for public use (i.e. main transportation routes, parks, schools and small commercial businesses).

In both towns the roads serve as the only drainage system collecting stormwater from the roofs, open areas and from the roads themselves. The roads are drained by street gutters into underground sewer systems (usually following the street network) that convey the water outside the city, i.e. to the natural stream of Nahal Ayalon, without any treatment. Although both towns have drainage systems, there is a considerable difference between them. In Ramallah only $40 \%$ of the area is connected to the stormwater draining system. Runoff from the remaining territory flows to open areas and infiltrates through the soil, finally recharging the groundwater. In Modiin, the urban sewer system carries the flows from the entire city to Nahal Anaba, a tributary of Nahal Ayalon (Fig. 3; Station M). In both towns the sewer and the sewage systems are separated. The sewage in Ramallah is partly treated by domestic septic tanks, still use in a large part of the households. From there polluted water directly infiltrates to the aquifer. The existing treatment plant is insufficiently 


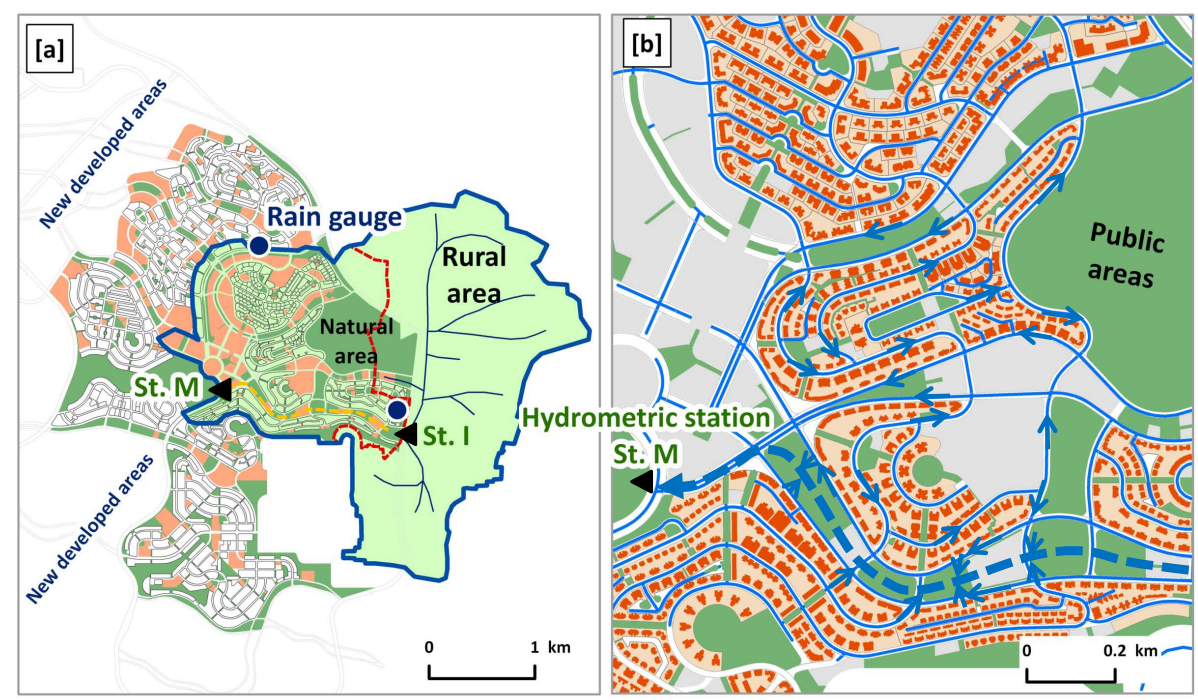

Fig. 3. (a) The city of Modiin and the hydrometeorological setup. Flow from the rural area upstream the town is measured by Station I (St. I). Station M (St. M) at the town outlet measures both the rural area (measured by St. I) and urban areas. One raingauge is located outside the map area; (b) Zoom into the urban center. Blue lines indicate flow lines of urban runoff: surficial on roads and subsurface culverts.

Table 2. Catchments area characteristics for each of the hydrometric stations. The Area is in $\mathrm{km}^{2}$ and the Length in $\mathrm{km}$. The \% values refer to the percentage of the specific landuse type.

\begin{tabular}{lrrrrr}
\hline Town & Station & Roofs & Roads & Roads & Unpaved \\
\hline \multirow{6}{*}{ Ramallah } & Code & Area & Area & Length & Area \\
& $\mathrm{km}^{2}$ & $\%$ & $\%$ & & $\%$ \\
& LS & 0.018 & 0.012 & 1.53 & 0.08 \\
& 0.11 & 16.4 & 10.9 & & 72.7 \\
& WA & 0.095 & 0.054 & 8.69 & 0.261 \\
& 0.41 & 23.2 & 13.2 & & 63.7 \\
& $\mathrm{~L}$ & 0.1 & 0.09 & 12.48 & 0.5 \\
& 0.69 & 14.5 & 13 & & 72.5 \\
\hline Modiin & $\mathrm{I}$ & 0.15 & 0.05 & 28.9 & 5.3 \\
& 5.5 & 2.7 & 0.9 & & 96.4 \\
& $\mathrm{M}-\mathrm{I}$ & 0.31 & 0.61 & 40.1 & 2.08 \\
& 3 & 10.3 & 20.3 & & 69.3 \\
& $\mathrm{~J}$ & & & & 1.1 \\
& 1.1 & & & & 100 \\
\hline
\end{tabular}

dimensioned and poorly treated sewage flows directly into the Ayalon stream. In Modiin the sewage is fully treated.

Both rapidly growing towns are situated on top of the karstic Yarkon-Taninnim aquifer (Fig. 1), which supplies about $350 \mathrm{M} \mathrm{m}^{3}$ of high-quality fresh water per year (about $25 \%$ of the freshwater demand). The water levels of this aquifer are found about $800 \mathrm{~m}$ and $200 \mathrm{~m}$ beneath the towns of Ramallah and Modiin respectively (Weinberger et al.,
1994). The karstic nature of this aquifer makes it vulnerable to anthropogenic pollution (Bachmat and Wollman, 2000) either by direct infiltration of stormwater through shallow soils or by infiltration of contaminated streamflow.

\section{Methodology}

The investigation was conducted during two periods: in Ramallah during the winter seasons of 1999/2000 and 2000/2001; in Modiin preliminary work was carried out during the winter season 2001/2002 and the complete set of measurements was collected in the following winter of 2002/2003.

\subsection{Maps and urban surveys}

Topographic maps of 1:50000, detailed air photographs and GIS-based data layers of DTM $(25 \mathrm{~m})$, roads, dwellings, sewer system etc. were obtained from both municipalities and used for high accuracy mapping of small urban segments. In addition, a $1 \mathrm{~m}$ resolution topographic contour map was obtained for Modiin. In the area topographic surveys date back to the British time (before 1940) and some maps are even from earlier periods. Hence, natural topography prior to urbanization was available for both towns and used to define changes created by urban development. Field surveys yielded information on the use of roof water and urban stormwater. 

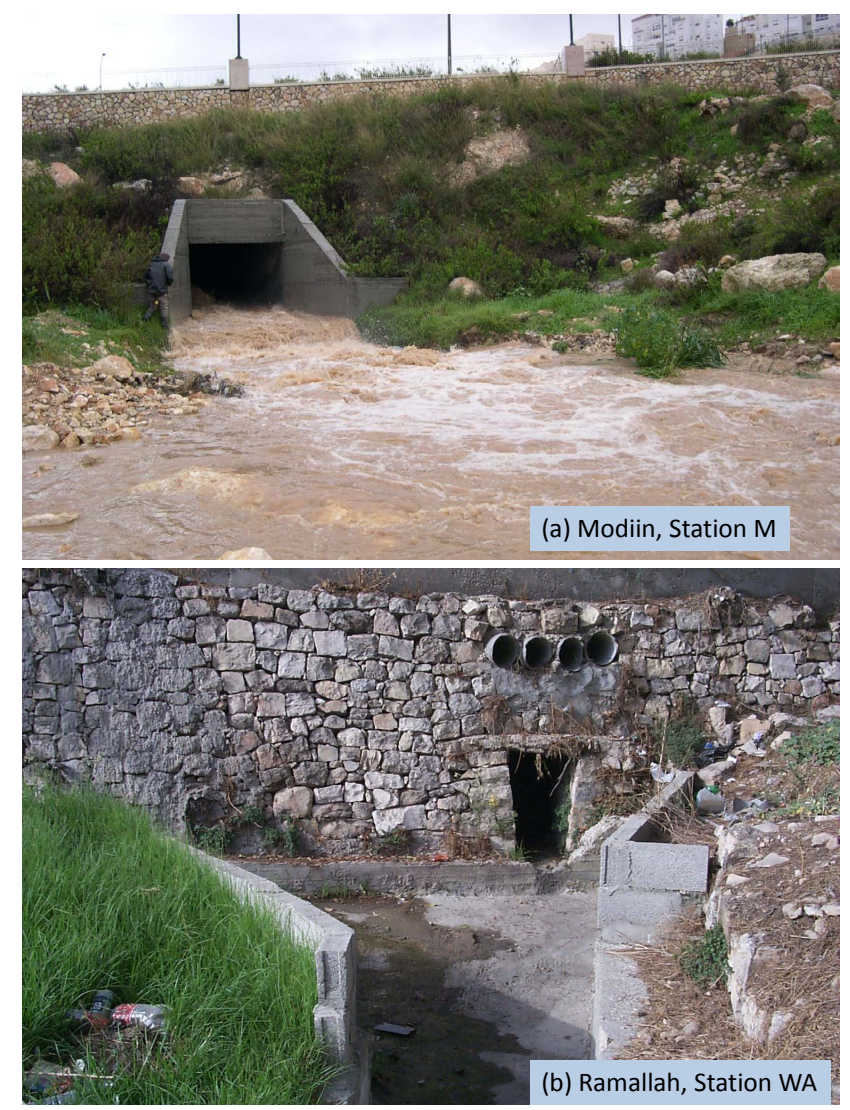

Fig. 4. The sewer culverts: (a) the outlet of the main storm water culvert in Modiin (Station M) and (b) the steep relief forced urban runoff at Station WA to concentrate at specific location (Station WA open culvert just before the gauging station).

\subsection{Rainfall}

Tipping bucket raingauges (ULTIMETER TB Rain Gauge fitted with Hoobo event datalogger) were used to determine rain intensities. In Ramallah a network of nine raingauges was installed to measure rainfall variability caused by the sharp relief (30\%). To obtain a representative value for catchment rainfall $\mathrm{CR}(\mathrm{mm})$ the following relation was used:

$\mathrm{CR}=(\mathrm{MR}+\mathrm{VR}) / 2$

where MR (mm) is the average rainfall collected by the ridge stations and VR $(\mathrm{mm})$ is the average rainfall collected by valley stations. In Modiin, a network of three raingauges was used as the general topography is relatively flat $(2 \%)$ and its effect on the spatial variability of rainfall was found to be negligible.

\subsection{Runoff quantity and quality}

In Modiin runoff was measured at two locations: at the entrance of the natural stream to the town (Station I; Fig. 3) and at its outlet (Station M; Figs. 3 and 4a). Station I measured
$5.5 \mathrm{~km}^{2}$ of rural areas upstream from the city - small villages, agricultural fields, natural areas and adjacent roads. It was installed at the inlet of the main storm water concrete culvert $(2 \times 2 \mathrm{~m})$ passing through the town. At the outlet of this culvert, $2.2 \mathrm{~km}$ downstream, Station $\mathrm{M}$ measured both rural runoff passing Station I and the runoff created in urban parts between the stations (total contributing area: $8.5 \mathrm{~km}^{2}$ ). The difference between stations $\mathrm{M}$ and I yielded the amount of urban runoff from the town core $\left(3 \mathrm{~km}^{2}\right)$, referred to as Station M-I. At Station M, electrical conductivity (range 0$5 \mathrm{mS} \mathrm{cm}^{-1}$ ) and temperature (accuracy of $2 \%$ and $0.1 \%$, respectively) were logged by LTC levelloggers (Solinst). These data were used to characterize urban contamination fluxes (Pellerin et al., 2008). To understand the impact of urbanization, a third station was placed in a natural first-order catchment in the town vicinity (Station $\mathrm{J} ; 1.1 \mathrm{~km}^{2}$ ). In Ramallah three stations were installed (Fig. 2a). Two neighborhoods were measured separately. Station LS $\left(0.11 \mathrm{~km}^{2}\right)$ was installed inside a concrete road manhole, which was later found to have limited inlet capacity during high storms. Station WA $\left(0.41 \mathrm{~km}^{2}\right)$ measured flow inside an open concrete culvert $(0.6 \times 0.6 \mathrm{~m}$; Fig. $4 \mathrm{~b})$. From both neighborhoods runoff joined in the main urban storm water sewer for a short distance and flooded a large open area before being conveyed again to the urban drainage system. At this point Station L $\left(0.69 \mathrm{~km}^{2}\right)$ was located inside a concrete through-flow pipe of $1.6 \mathrm{~m}$ diameter.

At all runoff stations pressure transducers (Druck, PTX series, range $0-1 \mathrm{~m}$ and accuracy $1 \%$ ) recorded water levels at 1-min time intervals. These values were converted to discharge using the HEC-RAS hydraulic model (US Army Corps of Engineers, 2001). Runoff coefficients, $c$ (\%) for single storm events in each station were calculated as follows:

$c=(\mathrm{Sv} / \mathrm{Rv}) \times 100$

where $\mathrm{Sv}\left(\mathrm{m}^{3}\right)$ is the total runoff volume measured per event and $\operatorname{Rv}\left(\mathrm{m}^{3}\right)$ is the total rainfall volume obtained by multiplying average rainfall by the area of the contributing catchment.

\subsection{Drainage Density Index - DDI}

To quantify the urbanization impact on runoff concentration the drainage density index (DDI) was defined:

$\mathrm{DDI}=\mathrm{DDr} / \mathrm{DDn}$

where DDr is density of the urban road network and DDn is the pre-urbanization drainage density. DDn was calculated by deliniation of streamlines from standardized GISanalysis (source: DTM $25 \mathrm{~m}$ ). First, flow accumulation from upstream cells was calculated for every grid cell. Stream cells were defined, when the number of upstream cells exceeded a threshold of 25 . Second, the total length of (theoretically existing) streams was divided by catchment area. 
Table 3. Storm events in Modiin, winter 2002/2003.

\begin{tabular}{|c|c|c|c|c|c|c|c|c|c|c|}
\hline Storm dates & $\begin{array}{l}\text { Rain } \\
\mathrm{mm}\end{array}$ & $\begin{array}{c}\text { Station I } \\
\text { Qp } \\
\mathrm{m}^{3} \mathrm{~s}^{-1}\end{array}$ & $\begin{array}{l}\text { Vol } \\
\mathrm{m}^{3}\end{array}$ & $\begin{array}{c}\text { Runoff } \\
\%\end{array}$ & $\begin{array}{l}\text { Station M- } \\
\qquad \mathrm{Qp} \\
\mathrm{m}^{3} \mathrm{~s}^{-1}\end{array}$ & $\begin{array}{l}\text { Vol } \\
\mathrm{m}^{3}\end{array}$ & $\begin{array}{c}\text { Runoff } \\
\%\end{array}$ & $\begin{array}{l}\text { Station } \mathrm{J} \\
\qquad \mathrm{Qp} \\
\mathrm{m}^{3} \mathrm{~s}^{-1}\end{array}$ & $\begin{array}{l}\text { Vol } \\
\mathrm{m}^{3}\end{array}$ & $\begin{array}{c}\text { Runoff } \\
\%\end{array}$ \\
\hline 5 Nov 2002 & 5.2 & 0.1 & 65 & 0.2 & 0.1 & 118 & 0.7 & 0 & 0 & 0 \\
\hline 23-25 Nov 2002 & 7.5 & 0.1 & 198 & 0.5 & 0.1 & 200 & 0.9 & 0 & 0 & 0 \\
\hline 29 Nov 2002 & 4.6 & 0.1 & 70 & 0.3 & 0.1 & 237 & 1.7 & 0 & 0 & 0 \\
\hline 9-10 Dec 2002 & 12.9 & - & - & - & 0.1 & 545 & 1.4 & 0 & 0 & 0 \\
\hline 11 Dec 2002 & 8.6 & - & - & - & 0.1 & 349 & 1.3 & 0 & 0 & 0 \\
\hline 16 Dec 2002 & 7.5 & - & - & - & 0.1 & 363 & 1.6 & 0 & 0 & 0 \\
\hline 17-18 Dec 2002 & 30.0 & - & - & - & 6.4 & 7257 & 8.1 & 0 & 0 & 0 \\
\hline 20-22 Dec 2002 & 58.3 & - & - & - & 6.4 & 28270 & 16.2 & 0 & 0 & 0 \\
\hline 24-25 Dec 2002 & 21.2 & 0.2 & 2189 & 1.9 & 5.6 & 12108 & 19.0 & 0 & 0 & 0 \\
\hline 27 Dec 2002 & 12.0 & 0.01 & 64 & 0.1 & 5.6 & 5240 & 14.6 & 0 & 0 & 0 \\
\hline 31 Dec 2002 & 7.1 & 0.1 & 530 & 1.4 & 0.1 & 1225 & 5.7 & 0 & 0 & 0 \\
\hline 3-4 Jan 2003 & 24.0 & 0.7 & 1210 & 0.9 & $11.4^{*}$ & 21428 & 29.8 & 0 & 0 & 0 \\
\hline 20-21 Jan 2003 & 53.9 & 0.2 & 3982 & 1.3 & 5.8 & 25690 & 15.9 & 0 & 0 & 0 \\
\hline 4-5 Feb 2003 & 15.9 & 0.1 & 897 & 1.0 & 0.9 & 3809 & 8.0 & 0 & 0 & 0 \\
\hline 8-10 Feb 03 & 25.7 & 0.1 & 1441 & 1.0 & 1.0 & 7551 & 9.8 & 0 & 0 & 0 \\
\hline 13-15 Feb 2003 & 57.3 & 0.2 & 10037 & 3.2 & 4.8 & 35696 & 20.8 & 0 & 0 & 0 \\
\hline 19-22 Feb 2003 & 46.4 & 0.2 & 4508 & 1.8 & 6.4 & 14030 & 10.1 & 0.01 & 2 & 0.01 \\
\hline 24-26 Feb 2003 & 143.7 & 1.5 & 71903 & 9.1 & 6.4 & 130722 & 30.3 & 1.3 & 47265 & 29.9 \\
\hline 27-28 Feb 2003 & 17.8 & - & - & - & 2.9 & 6627 & 12.4 & 0 & 0 & 0 \\
\hline 18-22 Mar 2003 & 75.4 & - & - & - & 4.8 & 15477 & 6.8 & 0 & 0 & 0 \\
\hline 24-26 Mar 2003 & 88.2 & 1.8 & 33446 & 6.9 & 6.4 & 67294 & 25.4 & 0 & 0 & 0 \\
\hline 21 Apr 2003 & 5.5 & - & - & - & 0.5 & 541 & 3.3 & 0 & 0 & 0 \\
\hline 27 Apr 2003 & 14.8 & - & - & - & 1.0 & 3615 & 8.1 & 0 & 0 & 0 \\
\hline
\end{tabular}

* reconst. peak Q

The total length of (theoretically existing) streams was divided by catchment area. For DDr the length of all urban roads were summarized and divided by catchment area. In general, drainage densities are scale-dependent. Therefore values underestimate natural drainage patterns and absolute values of DDI should be treated with caution.

\section{Results}

\subsection{Rainstorms}

All rainstorms are presented in Tables 3 and 4. In Ramallah, considerable variation between ridge and valley rainfall was observed due to the sharp relief (Fig. 5). This occurrence is due to stronger wind fields over the ridges that push the raindrops towards the valleys (e.g. Sharon 1970; Arazi et al., 1997; Sharon et al., 2000). In general, this phenomenon intensifies with storm magnitude. Figure 5 clearly shows that valley stations received significant higher rainfall amount compared to ridge stations. This relation (ridgevalley, Fig. 5) was used for CR calculations whenever valley stations failed to operate, especially during the second season. We determined the regression curve twice: (a) with all recorded values (VR $=1.6 \mathrm{MR}$; Fig. 5a) and (b) omitting the

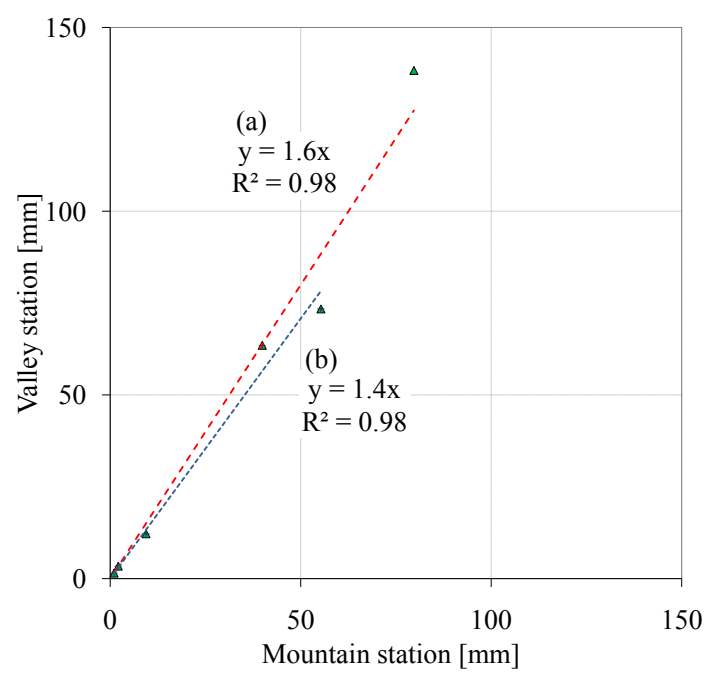

Fig. 5. Ramallah: valley station plotted against ridge station: (a) with all measured substorms rainfall data and (b) excluding the extreme value. 
Table 4. Storm events in Ramallah during winter seasons 1999/2000 and 2000/2001.

\begin{tabular}{|c|c|c|c|c|c|c|c|c|c|c|}
\hline Storm dates & $\begin{array}{l}\text { Rain } \\
\mathrm{mm}\end{array}$ & $\begin{array}{c}\text { Station WA } \\
\text { Qp } \\
\mathrm{m}^{3} \mathrm{~s}^{-1}\end{array}$ & $\begin{array}{l}\text { Vol } \\
\mathrm{m}^{3}\end{array}$ & $\begin{array}{c}\text { Runoff } \\
\%\end{array}$ & $\begin{array}{c}\text { Station LS } \\
\text { Qp } \\
\mathrm{m}^{3} \mathrm{~s}^{-1}\end{array}$ & $\begin{array}{l}\text { Vol } \\
\mathrm{m}^{3}\end{array}$ & $\begin{array}{c}\text { Runoff } \\
\%\end{array}$ & $\begin{array}{c}\text { Station L } \\
\text { Qp } \\
\mathrm{m}^{3} \mathrm{~s}^{-1}\end{array}$ & $\begin{array}{l}\text { Vol } \\
\mathrm{m}^{3}\end{array}$ & $\begin{array}{c}\text { Runoff } \\
\%\end{array}$ \\
\hline 14-15 Dec 1999 & 10.5 & 0.03 & 71 & 1.6 & - & - & - & 0.00 & 1 & 0.0 \\
\hline 24 Dec 1999 & 1.4 & 0.01 & 8 & 1.4 & - & - & - & 0.00 & 0 & 0.0 \\
\hline 4-6 Jan 2000 & 64.4 & 0.12 & 1485 & 5.6 & - & - & - & 0.13 & 1820 & 4.1 \\
\hline 10-11 Jan 2000 & 3.0 & 0.02 & 14 & 1.1 & 0.00 & 2 & 0.6 & 0.00 & 0 & 0.0 \\
\hline 18-23 Jan 2000 & 107.1 & 0.99 & 5433 & 12.4 & 0.25 & 1644 & 10.0 & 0.86 & 12041 & 16.3 \\
\hline 26-31 Jan 2000 & 63.3 & 0.50 & 2194 & 8.5 & 0.14 & 1390 & 20.0 & 0.44 & 3415 & 7.8 \\
\hline 12-14 Feb 2000 & 48.4 & 0.32 & 2015 & 10.2 & - & - & - & 0.32 & 3065 & 9.2 \\
\hline 1-2 Mar 2000 & 46.8 & 0.46 & 1898 & 9.9 & 0.10 & 946 & 18.4 & 0.37 & 3446 & 10.7 \\
\hline 1 Dec 2000 & 9.1 & 0.18 & 174 & 4.7 & 0.07 & 97 & 9.7 & 0 & 0 & 0.0 \\
\hline $9 / 12 / 00$ & 9.6 & 0.07 & 291 & 7.4 & 0.07 & 84 & 8.0 & 0.004 & 33 & 0.5 \\
\hline 11-14 Dec 2000 & 29.5 & 0.51 & 1677 & 13.9 & 0.18 & 634 & 19.5 & - & - & - \\
\hline 23-25 Jan 2001 & 25.9 & 0.09 & 901 & 8.5 & 0.22 & 995 & 34.9 & - & - & - \\
\hline 3-4 Feb 2001 & 32.2 & 0.10 & 1331 & 10.1 & 0.10 & 607 & 17.1 & 0.342 & 1865 & 8.4 \\
\hline 5 Feb 2001 & 2.6 & 0.02 & 71 & 6.7 & 0.02 & 35 & 12.2 & 0 & 0 & 0.0 \\
\hline 17 Feb 2001 & 9.5 & 0.20 & 359 & 9.2 & 0.11 & 231 & 22.1 & 0.402 & 874 & 13.3 \\
\hline 20-21 Feb 2001 & 13.7 & 0.43 & 824 & 14.7 & 0.11 & 274 & 18.2 & 0.226 & 782 & 8.3 \\
\hline 2 May 2001 & 26.1 & 0.56 & 1293 & 12.1 & - & - & - & 0.518 & 2521 & 14.0 \\
\hline
\end{tabular}

two highest storms (VR=1.4 MR; Fig. 5b). In Modiin, the moderate relief created a uniform rainfall distribution which was adequately represented by the three raingauges. They showed similar rainfall totals, except during one storm with rainfall less than $10 \mathrm{~mm}$.

\subsection{Rainfall-runoff relationships}

Plotting runoff coefficients against storm rainfall, $R^{2}$ values ranged between 0.3-0.46 in Ramallah (stations WA, LS and L) and 0.64 in Modiin (Station M-I), compared to 0.89 in the rural area of Modiin (Station I, Fig. 6). To include rainfall uncertainty, we used both rainfall correlation factors ( 1.4 and 1.6, as described above) for the calculation of runoff coefficients. In Ramallah, the upper stations LS and WA responded almost instantaneously to $1-4 \mathrm{~mm}$ of rainfall, with maximum runoff coefficients of $35 \%$ and $16 \%$, respectively, during the largest storms. At Station L, downstream the open area, a threshold of about $12 \mathrm{~mm}$ was required for runoff initiation and maximum runoff coefficients reached $22 \%$. In Modiin, the runoff coefficient during the extreme event $(30.3 \%$, Station $\mathrm{M}-\mathrm{I})$ reached almost the same value as measured in the natural area $(29.9 \%$, Station J; Table 3$)$. The lowest runoff coefficient was measured in the rural area $(9.1 \%$, Station I).

\subsection{High magnitude events}

During the study periods one rainstorm in each town exceeded $100 \mathrm{~mm}$ (Tables 3 and 4). Both events were characterized by a distinct configuration. A few days of continuous low-intensity rainfall were followed by a short high-intensity

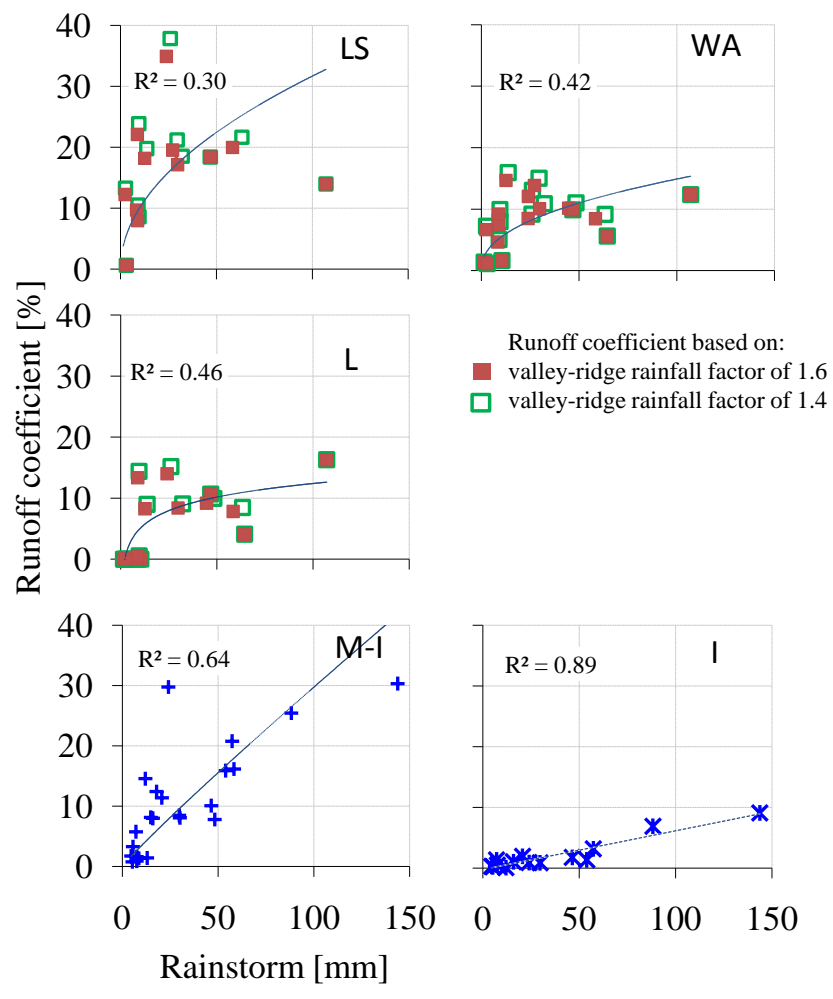

Fig. 6. Complete record of runoff percentages for the hydrometric stations in Ramallah (WA, LS and L) and Modiin (I and M). Station $\mathrm{J}$ (Modiin) is not included as only one storm generated runoff during the investigated period. 
Table 5. Runoff response during two high-magnitude events: Ramallah (a1-a2) and Modiin (b1-b2).

\begin{tabular}{lrrrr}
\hline Ramallah & $\begin{array}{r}\text { Pre-storm date } \\
\text { (a1) 18-19 Jan 2000 }\end{array}$ & $\begin{array}{r}\text { rain } \\
23.5 \mathrm{~mm}\end{array}$ & $\begin{array}{r}\text { Main-storm date } \\
\text { (a2) 20-21 Jan 2000 }\end{array}$ & $\begin{array}{r}\text { rain } \\
83.6 \mathrm{~mm}\end{array}$ \\
& Volume & Runoff & Volume & Runoff \\
& $\mathrm{m}^{3}$ & $\%$ & 1230 & 14.1 \\
\hline LS & 368 & 12.6 & 4791 & 19.3 \\
WA & 793 & 10.9 & 11566 & 20.0 \\
L & 1853 & 11.4 & & \\
\hline & & & & \\
\hline Modiin & Pre-storm date & rain & Main-storm date & rain \\
& (b1) $19-23$ Feb 2003 & $46.4 \mathrm{~mm}$ & (b2) 24-26 Feb 2003 & $143.7 \mathrm{~mm}$ \\
& & & Volume & Runoff \\
& Volume & Runoff & $\mathrm{m}^{3}$ & $\%$ \\
\hline St. I & $\mathrm{m}$ & $\%$ & 71903 & 9.1 \\
St. M & 4508 & 1.8 & 202625 & 16.6 \\
St. M-I & 19121 & 4.8 & 130722 & 30.3 \\
\hline
\end{tabular}

rainfall spell (Table 5). In Ramallah a rainstorm of $107.1 \mathrm{~mm}$ occurred after a week of dry weather and included two main sub-storms: $23.5 \mathrm{~mm}$ and $83.6 \mathrm{~mm}$ (Table 5; Fig. 7). The first rain spell produced roughly equal runoff coefficients at all stations: LS (12.6\%), WA (10.9\%) and L (11.4\%). The second rain spell increased the runoff volume at Station LS by a factor of 3 , but the runoff coefficient (14.1\%) remained almost the same. This was explained by the limited inlet capacity of the stormwater culvert. The culvert was located on the right side of a steep road. During low-medium flows all the runoff was captured by the culvert, whereas during peak flow of the high event, runoff exceed the capacity of the culvert inlet and a large part continued flowing on the road surface to reach an open area. At stations WA and L the runoff volume during the second rain spell was approximately 6 times higher than during the first spell and runoff coefficients doubled, reaching $19.3 \%$ and $20 \%$, respectively. In Modiin a rainstorm of $190.1 \mathrm{~mm}$ occurred after three and a half days of dry weather and was characterized by two main storm cores: $46.4 \mathrm{~mm}$ and $143.7 \mathrm{~mm}$ (Table 5; Fig. 8). The first rain spell resulted in runoff coefficients of $1.8 \%$ in the rural area (Station I) and $10.1 \%$ in the town center (Station M-I). The second rain spell increased the runoff volume at Station I by a factor of 16 and the runoff coefficient by a factor of 5. At Station M-I the runoff volume was 9 times higher and the runoff coefficient increased by a factor of 3 . In the neighboring natural area (Station J) runoff was generated only during the second rain spell with a runoff coefficient of $30 \%$.

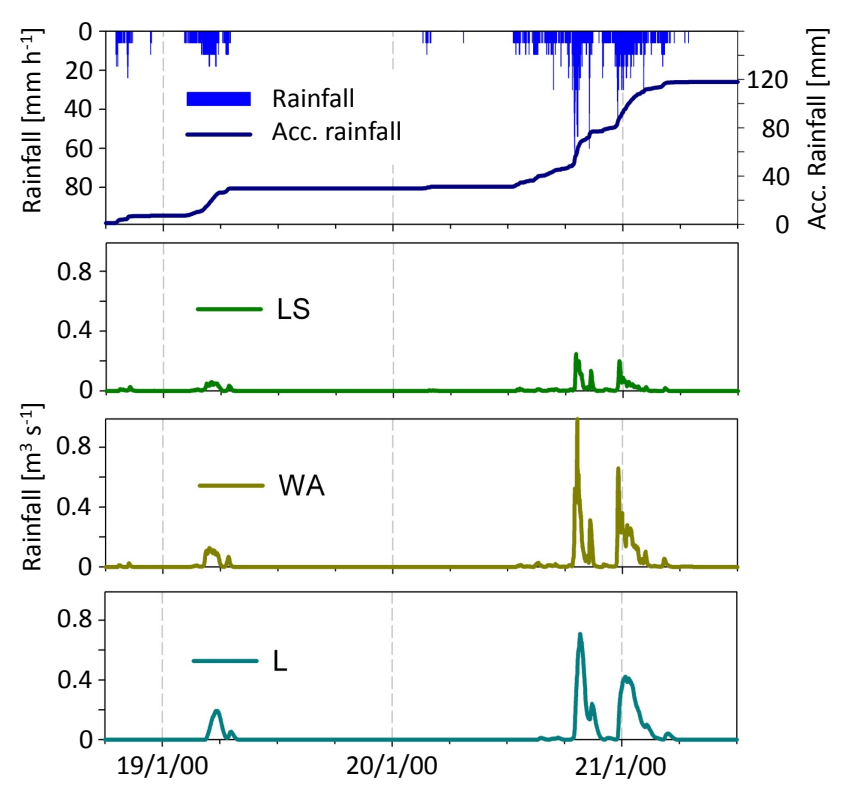

Fig. 7. The high-magnitude event measured at three gauging stations in Ramallah. Note: rainfall is taken from valley station.

\subsection{Hydrograph shape}

In general, all urban hydrographs were characterized by instantaneous runoff responses, 1 to $11 \mathrm{~min}$ after rain onset with steep rising limbs reaching peak values after an additional 5 to $10 \mathrm{~min}$. Flow recession lasted for about one hour following the cessation of rainfall. However, the geometry of the urban drainage network dictated hydrograph shape (Fig. 9): (i) a single main flow route generated single 

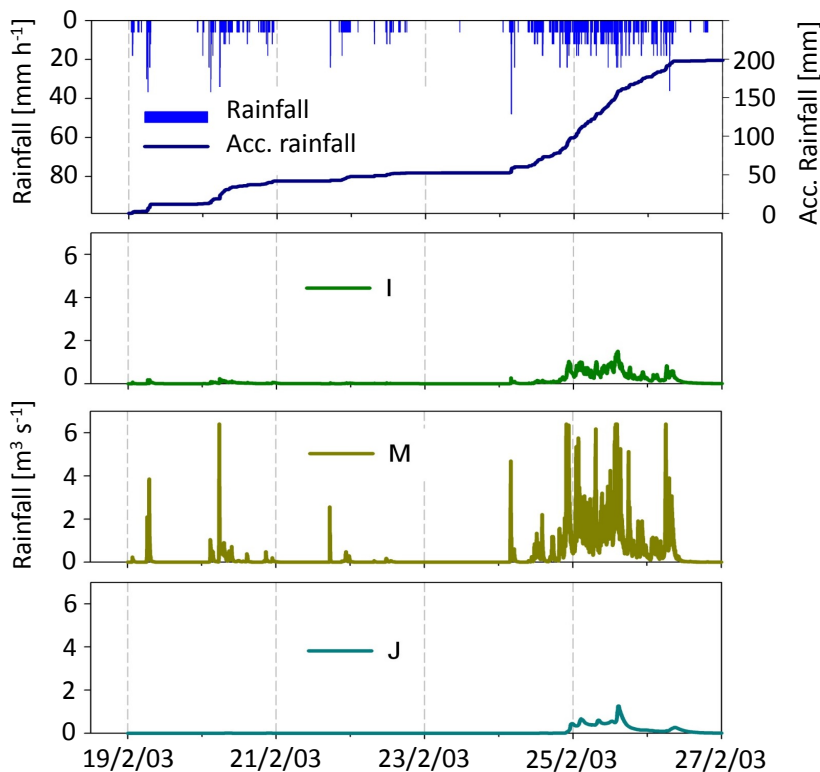

Fig. 8. The extreme event in the Modiin region. Note that station M runoff includes runoff from station I.

peak hydrographs (Fig. 9a; Station LS in Ramallah); (ii) a more complex road network generated secondary, smaller peaks (Fig. 9b; Station WA in Ramallah); (iii) the new urban setting in Modiin, characterized by a dense network of parallel and perpendicular roads, generated a sequence of similar runoff peaks (Fig. 9c). Although Station I drained a large rural area, only a nearby main road contributed to runoff and produced a single discharge peak during small rainfalls. While a similar peak magnitude was observed at Station M, the larger draining road area caused a higher runoff volume and longer flow duration of sequentially arriving runoff peaks (Station I: $0.15 \mathrm{~m}^{3} \mathrm{~s}^{-1}, 65 \mathrm{~m}^{3} / 20 \mathrm{~min}$; Station M: $0.12 \mathrm{~m}^{3} \mathrm{~s}^{-1}, 137 \mathrm{~m}^{3} / 90 \mathrm{~min}$ ).

\subsection{Urban pollution}

In both towns the time span between winter rainstorms was a few weeks, allowing urban contaminants to concentrate on the road network. The first rain spells after dry periods flushed these contaminants away. As a result, peaks in electrical conductivity were observed at Station M in Modiin. In addition, throughout the year (during both rainy and dry seasons), flows from a variety of urban sources (e.g., leaks in water/sewage pipes and irrigation systems, water from car washes, etc.) were observed entering road receptors in the storm sewers of Modiin. These flows were additionally polluted by residential waste deposited in the sewer system and entered the natural river downstream the city without any treatment. Although the volume of the pollution events are negligible compare to the natural flows (few orders of magnitudes), their impact on the environment is high. As an example a flow with electrical conductivity values reaching

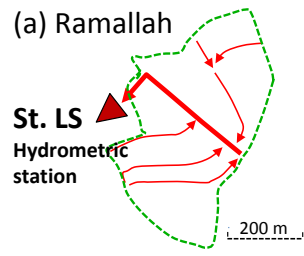

(b) Ramallah
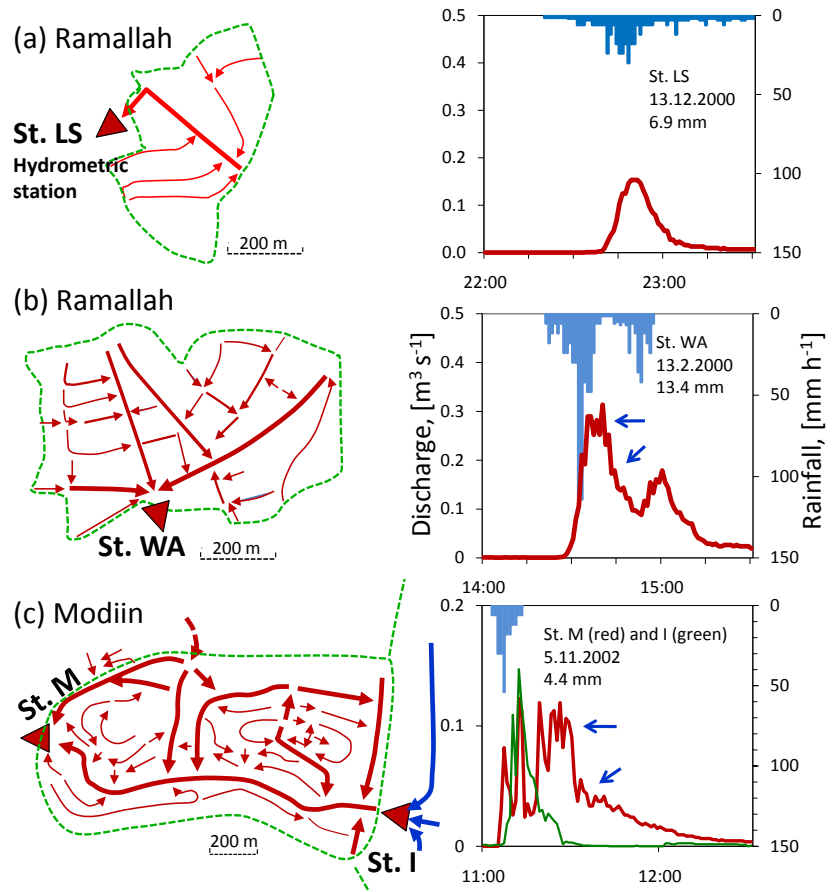

Fig. 9. Urban road network design and the hydrological response following small rainstorms. Note blue arrows indicate multi-peaks at the peak discharge and also at the recession.

almost $4 \mathrm{mS} \mathrm{cm}^{-1}$ was measured in the stormwater sewer pipe of Modiin at Station M. This high contaminant load was measured without preceding rainfall, just before the first seasonal rain (Fig. 10). Later, following natural rainfall, a typical urban runoff hydrograph was recorded with a short initial peak in electrical conductivity documenting the first flush which was afterwards diluted by urban stormwater.

\section{Discussion}

Urban design on steep mountainous terrains forces planners to level topography into a series of parallel roads and terraces. The latter are used for houses with adjacent gardens, usually bounded by concrete walls. These dwelling units are hydrologically disconnected from the urban drainage system and create favorable areas for direct in situ recharge. Roofs make up to $50 \%$ of the dwelling area and normally contribute rainwater to irrigate the attached gardens. Since $19 \%$ of the houses in Ramallah still use cisterns to collect rainfall from the roofs, small rainstorms that usually evaporate become important water sources. When used for domestic purposes, cistern water will finally become waste water reducing urban groundwater recharge. However, the overall effect of cisterns on the urban water balance depends on the individual water use and is hard to estimate (at least during high magnitude events it can be assumed to be marginal, because then 


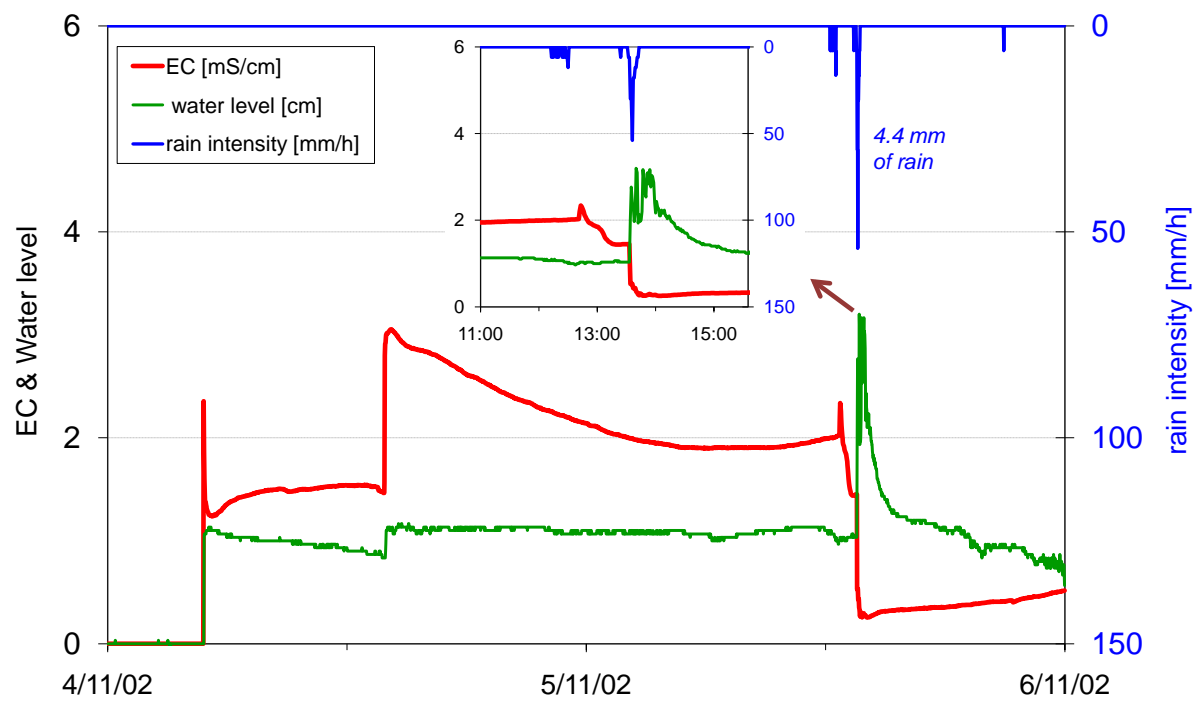

Fig. 10. Measured runoff quantity and electrical conductivity (EC) at Station M, Modiin at the beginning of the rainy season.

the total capacity of the cisterns is negligible compare to the rainstorm volume).

In the Eastern Mediterranean spatial variability of rainfall is considerable, as evidenced by e.g. rainfall radar images (Karklinsky and Morin 2006). For this reason we analyzed measured rainfall from various stations in both cities. In Modiin, only a minor discrepancy was found, whereas the accentuated relief in Ramallah caused a significant and systematic difference between two types of stations: ridge and valley. Throughout the study period the number of operational stations varied, but in general, more ridge stations produced data than valley stations. Hence, simple geostatistic methods (e.g. Inverse Distance Weighting, Thiessen Polygons) would have blurred spatial rainfall estimates giving too much weight to ridge stations. This would have been most prominent in the second year when all valley stations failed to operate. Under these circumstances our simplified procedure was assumed to yield more robust and balanced estimates of catchment rainfall.

Excluding the dwelling units, road networks became the main source for urban storm runoff in our study. Roads could also explain immediate runoff responses following small rainstorms (two-thirds of the rainstorms did not exceed $15 \mathrm{~mm}$ ). Small rainstorms were totally absorbed in the surrounding natural terrain (Station J; Table 3). In both cities, relatively small runoff coefficients showed that quite considerable water volumes were lost in areas other than road or sewer systems. Hence, only marginal contributions from sources other than roads could be expected during small events. One exception was Station LS, the smallest catchment where water losses were less pronounced. A scale effect of urban runoff generation could thus be observed with higher stormwater losses in larger catchment areas. This effect was more significant in the complex and less-organized sewer system of the traditional town of Ramallah.
In both cities the locations of the runoff stations were carefully selected to prevent bypass flow. In Modiin, systematic urban design directed all surface flow to the main storm sewer. Its large dimension $(2 \times 2 \mathrm{~m}$; Fig. $4 \mathrm{a})$ prevented any overtopping also during extreme events. In Ramallah, the steep relief (Figs. 2 and 4 b) forced urban runoff to concentrate at specific locations. These were selected for runoff gauging. Again, the dimensions of the sewer systems (pipes and concrete channels) were capable to conduct the entire storm runoff from the catchments upstream. The only exception was Station LS, which was installed inside a road manhole with limited inlet capacity.

Interestingly, a paradox was observed during the heaviest rainstorm in Modiin (143.7 mm; Table 5): a similar runoff coefficient (about 30\%) was measured from both the city (Station M-I) and from the nearby natural terrain (Station J; Table 3). Conceptually, a gradual increase in runoff percentage can be expected as a rainstorm progresses (e.g., Lange et al., 2003), since more and more areas within the catchment (natural and urban areas) participate in runoff generation. This increase was observed in the natural catchment, but not in the cities: while urban roads, public parks and natural areas contributed to runoff, the closed terraced dwelling units were all the time disconnected from the runoff response. These areas were estimated to constitute $20 \%$ of the entire urban catchment and also included a part of the roofs draining directly to the closed and fenced gardens. Therefore, a runoff coefficient of about $30 \%-35 \%$ is suggested to be the maximum value to be expected from comparable mountainous Middle Eastern cities. This value is well below textbook values usually used for urban design. In the Rational Method, for example, runoff coefficients typically exceed $50 \%$ or even $70 \%$ for downtown areas (Akan and Houghtalen, 2003).

These single extreme events dominate the seasonal water balance in the Mediterranean climate. For Modiin 
Table 6. Drainage density (DDI): natural areas previous to urbanization versus roads - Modiin and Ramallah.

\begin{tabular}{lllllrrr}
\hline City & Station & $\begin{array}{l}\text { Area, } \\
\mathrm{km}^{2}\end{array}$ & $\begin{array}{l}\text { Channel L } \\
\mathrm{km}\end{array}$ & $\begin{array}{l}\text { Natural Den., } \\
\text { DDn km }\end{array}$
\end{tabular}

similar runoff rates in urban and natural areas $\left(441 \mathrm{~m}^{-2}\right.$ and $431 \mathrm{~m}^{-2}$, respectively) were observed. However, their annual share was markedly different. In the natural catchment (Station J) this event was responsible for almost the entire seasonal flow (96\%). Previous small rainfall events were absorbed on the natural hillslopes and a seasonal threshold of about $400 \mathrm{~mm}$ of rainfall was required for first runoff generation. At the same time, urban areas had already reacted several times following small rain storms passing a marginal seasonal rainfall threshold of 1-4 mm. Consequently, the high magnitude storm made up only $34 \%$ of seasonal runoff.

Combining field observations and measured data, a simple conceptual model was created assigning rainfall and runoff coefficients to different urban elements contributing runoff (Fig. 11). The data of the model is based on average runoff coefficients measured at each station. Up to $15 \mathrm{~mm}$ of rainfall, urban roads are the only runoff source. They are responsible for a quick, instantaneous runoff response. When rainfall increases more and more roads contribute to runoff until the entire road network is active. More rainfall may activate also roofs and parking lots. However, about half of the roofs are connected to closed gardens and hence remain disconnected from the urban runoff response. During high magnitude rainstorms also runoff contributions from public gardens and natural areas were observed. Still terraced areas remained disconnected and prevented higher runoff coefficients.

Our analyses on the impact of urbanization on runoff concentration suggests that DDI - the ratio between the natural and urban drainages densities - may be a practical tool (Table 6). Natural runoff is generated as overland flow on slopes and concentrated into channels where flows are routed downstream. In contrast, urban runoff is generated mainly on roads and only later (if the storm is large enough) other urban units add their share. In all urban stations DDr was found to be higher by an order of magnitude than DDn. Hence, the proposed index DDI may serve as a measure for the rate of hydrologic urbanization of an area. Since mainly agricultural/natural areas and only two small villages were drained, the DDI index for the rural area Station I in Modiin was found to be smallest (3.3; Table 6). The urban Station MI had higher DDI (5.3). This was still lower in comparison

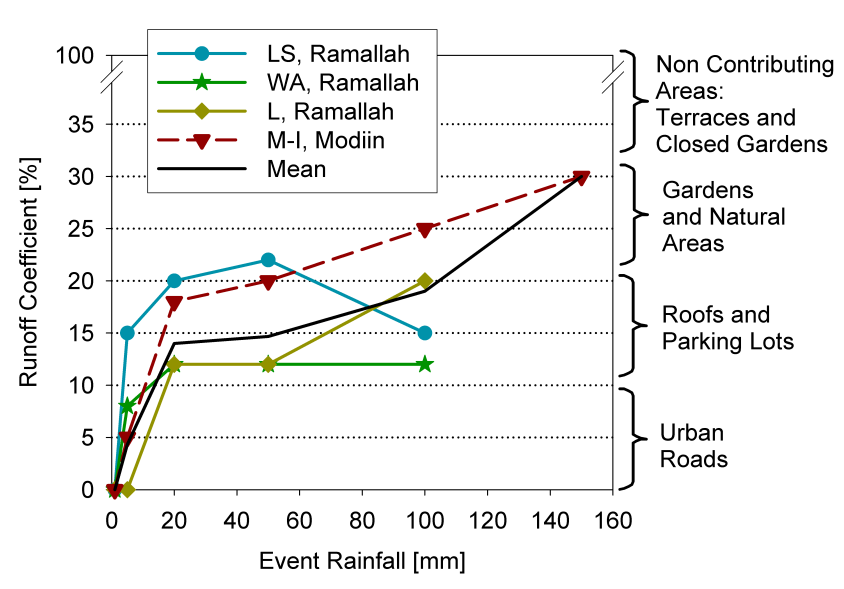

Fig. 11. Conceptual model for sequential runoff generation inside the two cities.

with the Ramallah stations since it included recreation areas and natural reserves. In Ramallah all stations showed rather high DDIs, suggesting high urban impact.

The open area in Ramallah influenced the flow pattern between the Stations WA and L by delaying the runoff response at $\mathrm{L}$ by almost $30 \mathrm{~min}$ and reducing hydrograph peaks. During small rainstorms (under $8 \mathrm{~mm}$ or $400 \mathrm{~m}^{3}$ ) the open area acted as a runoff barrier detaining urban runoff from the upstream stations (Table 4). During larger rainstorms runoff volumes between the stations were comparable. Then, runoff losses in the open area tended to be balanced by lateral runoff contributions. During the largest rainstorm the open area also generated runoff, and the runoff volume at Station L was larger than the combined flow from Stations LS and WA. Since urban areas respond during relatively small events, discontinuities in urban systems may be seen as favorable spots for groundwater recharge.

However, special care must be taken when managing stormwater in the investigated region for two main reasons. First, the long dry summers and the dry periods between individual rain events allow urban contaminants to concentrate on the road network. These contaminants reach natural rivers downstream the city (or open areas inside the town, as illustrated in the case of Ramallah) within the first rain 
flush. Second, observations in Modiin proved that even in modern cities polluted artificial flows from various urban sources reach the storm water sewers during times of zero rainfall. In Modiin a well organized collection system prevents waste water from entering the storm water sewer. Still various urban activities were observed generating polluted water to the sewer system: car washing, cleaning yards and balconies, oil leakage from cars etc. The conductivity values for such flows were found to exceed $4 \mathrm{mS} \mathrm{cm}^{-1}$, suggesting high concentrations of various pollutants. This type of pollution can hardly be controlled and the polluted water is not diluted as it is in the case of natural rainstorms. Hence, it must be seen as an extreme hazard for the underlying karstic aquifer and for people living in areas downstream.

\section{Conclusions}

Both cities investigated are located in mountainous terrain and may be seen as typical examples for many Mediterranean towns. The following conclusions may thus serve as hydrological guidelines for urban development in this specific region.

1. Although the road network typically covers only 10 $20 \%$ of the urban area, it dominates the hydrological response and the major hydrological change between urban and natural areas: (a) roads (also roofs drained into the roads) are the first and principal urban runoff generators, respond following $1 \mathrm{~mm}$ of rainfall and form the only storm water source area during small to medium events. Additional urban units contribute runoff only during high magnitude events. (b) The structure of the road network has a direct impact on hydrograph shape, runoff volume, peak discharge and lag time. Flow along parallel roads generates multi-peak hydrographs from single rainstorms with increased duration and reduced peak discharge. In well-planned modern cities this effect tends to be more pronounced than in old traditional townships.

2. The mountainous Mediterranean cities have relatively limited area for runoff generation. This phenomenon is valid for all storm magnitudes. Maximum runoff coefficients do not exceed a certain upper limit, which can partly be attributed to artificial terraces and fenced gardens inside cities. The upper limit of urban runoff generation suggests that larger volumes of urban stormwater may contribute to groundwater recharge than expected. Here especially, open areas inside urban storm water drainage systems may add a significant portion.

3. The use of urban storm runoff requires caution, because of its reduced quality. This is mainly caused by flushing pollutants from urban roads (runoff generators and distributors) or by illegal waste water disposal in the urban sewer systems. In general, the limited runoff generation from both investigated cities implies a large potential for urban groundwater recharge. However, additional measures to monitor and improve water quality are needed to safeguard groundwater quality.

For the first time in the eastern Mediterranean, this paper provides comparable measured hydrological data to assess the impact of urbanization in mountainous limestone terrain. In the light of a tremendous population growth, this data may help to arrive at sapient decisions for a sustainable future water management in this water scarce region.

Acknowledgements. This long-term monitoring study was funded by the German Science Foundation in the framework of a trilateral German-Palestinian-Israeli science support program and GLOWA - Jordan River Project, funded by the German Ministry of Science and Education in collaboration with the Israeli Ministry of Science and Technology. The authors wish to thank Marwan Hassan, Khaled Shain and the Palestinian Hydrology Group, for their contribution in the early stage of this study.

Edited by: L. Pfister

\section{References}

Akan, O. A. and Houghtalen, R. J.: Urban hydrology, hydraulics, and stormwater quality-Engineering applications and computer modeling, John Wiley \& Sons, Inc., Hoboken, New Jersey, 2003.

Arazi, A., Sharon, D., Khain, A., Huss, A., and Mahrer, Y.: The windfield and rainfall distribution induced within a small valley: field observations and 2-D numerical modelling, Bound.Lay. Meteorol., 83(3), 349-374, 1997.

Aryal, R. K., Furumai, H., Nakajima, F., and Boller, M.: Characteristics of particle-associated PAHs in a first flush of a highway runoff, Water Sci. Technol., 53(2), 245-251, 2006.

Ashley, R., Blanksby, J., Cashman, A., Jack, L., Wright, G., Packman, J., Fewtrell, L., Poole, T., and Maksimovic, C.: Adaptable urban drainage: Addressing change in intensity, occurrence and uncertainty of stormwater (AUDACIOUS), Built Environ., 33(1), 70-84, 2007.

Bachmat, Y. and Wolman, S. H.: Evaluation of the vulnerability of the Western Mountain Aquifer to pollution, Water Sci. Technol., 42(1-2), 417-421, 2000.

Bedient, B. P. and Huber, W. C.: Hydrology and Floodplain Analysis, Addison Wesley Reading, Massachusetts, USA, 1992.

Cheng, S. and Wang, R.: An approach for evaluating the hydrological effects of urbanization and its application, Hydrol. Process., 16, 1403-1418, 2002.

Dayan, U., Ziv, B., Margalit, A., Morin, E., and Sharon, D.: A severe autumn storm over the middle-east: synoptic and mesoscale convection analysis, Theor. Appl. Climatol., 69, 103-122, 2001.

Dunne, T. and Leopold, L. B.: Water in Environmental Planning, Freeman and Company, San Francisco, USA, 1978.

Feitelson, E. and Haddad, M. (Eds.): Management of shared groundwater resources: the Israeli-Palestinian case with an international perspective, Kluwer Academic Publishers, Boston, USA, 2000. 
Garnaud, S., Mouchel, J. M., Chebbo, G., and Thevenot, D. R.: Heavy metal concentrations in dry and wet atmospheric deposits in Paris district: comparison with urban runoff, Sci. Total Environ., 235(1-3), 235-245, 1999.

Garti, R., Arbel, S., and Getker, M.: Urbanization increasing peak discharge and the runoff percentage, truth or myth? Israeli Ministry of Agriculture, Soil Conservation Unit, Station for Erosion Investigation, Special Report M-43, 1-18, 1993.

Gnecco, I., Berretta, C., Lanza, L. G., and La Barbera, P.: Storm water pollution in the urban environment of Genoa, Italy, Atmos. Res., 77, 60-73, 2005.

Goldreich, Y. and Ronen, D. (Eds.): The climate of Israel: observation, research, and application, Kluwer Academic/Plenum Publishers, New York, 2003.

Graber, E. R., Laor, Y., and Ronen, D.: Aquifer contamination by chlorinated-VOCs; the case of an urban metropolis megasite overlying the Coastal Plain Aquifer in Israel, Hydrogeol. J., 16(8), 1615-1623, 2008.

Grodek, T., Lekach, J., and Schick, A. P.: Urbanizing alluvial fans as flood-conveying and flood-reducing systems: lessons from the October 1997 Eilat flood, in: The Hydrology-Geomorphology Interface: Rainfall, Floods, Sedimentation, Land Use, edited by: Hassan, M. A., Slaymaker, O., and Berkowicz, S. M., IAHS Publ., 261, 229-250, 2000.

Hassan, M. A., McIntyre, G., Klinkenberg, B., Tamimi, A., Paisely, R. K., Diabat, M., and Shahin, K.: Palestinian Water I: Resources, Allocation and Perception, Geography Compass, 4(2), 118-138, 2010a.

Hassan, M. A., Shahin, K., Klinkenberg, B., McIntyre, G., Diabat, M., Tamimi, A., and Nativ, R.: Palestinian Water II: Climate change and landuse, Geography Compass, 4(2), 139-159, $2010 \mathrm{~b}$.

Hollis, G. E. and Ovenden, J. C.: The quantity of stormwater runoff from ten stretches of road, a car park and eight roofs in Hertfordshire, England during 1983, Hydrol. Process., 2, 227-243, 1988.

Karklinsky, N. and Morin, E.: Spatial characteristics of radarderived convective rain cells over southern Israel, Meteorol. Z., 15(5), 513-520, 2006.

Kondoh, A. and Nishiyama, J.: Changes in hydrological cycle due to urbanization in the suburb of Tokyo Metropolitan area, Japan, Adv. Space Res., 26, 1173-1176, 2000.

Lange, J., Greenbaum, N., Husary, S., Ghanem, M., Leibundgut, C., and Schick, A. P.: Runoff generation from successive simulated rainfalls on a rocky, semi-arid, Mediterranean hillslope, Hydrol. Process., 17, 279-296, 2003.

Lee, J. H. and Bang, K. W.: Characterization of urban stormwater runoff, Water Res., 34(6), 1773-1780, 2000.

Lee, J. H., Bang, K. W., Ketchum, L. H., Choe, J. S., and Yu, M. J.: First flush analysis of urban storm runoff, Sci. Total Environ., 293(1-3), 163-175, 2002.

Lee, J. H., Yu, M. J., Bang, K. W., and Choe, J. S.: Evaluation of the methods for first flush analysis in urban watersheds, Water Sci. Technol., 48(10), 167-176, 2003.

Lerner, D. N.: Groundwater recharge in urban areas, Atmos. Environ., 24B(1), 29-33, 1990.

Li, L. Q., Yin, C. Q., He, Q. C., and Kong, L. I.: First flush of storm runoff pollution from an urban catchment in China, J. Environ. Sci., 19(3), 295-299, 2007.
Maidment, D. R.: Applications of geographic information systems in hydrology and water resources management, Proc. international conference, Vienna, IAHS, 211, 181-192, 1993.

Mangani, G., Berloni, A., Bellucci, F., Tatano, F., and Maione, M.: Evaluation of the pollutant content in road runoff first flush waters, Water Air Soil Poll., 160(1-4), 213-228, 2005.

Martin, C., Ruperd, Y., and Legret, M.: Urban stormwater drainage management: The development of a multicriteria decision aid approach for best management practices, Eur. J. Oper. Res., 181, 338-349, 2007.

Mizyed, N.: Land use management in the context of joint management of shared aquifers, in: Management of Shared Groundwater Resources: the Israeli-Palestinian Case with an International Perspective, edited by: Feitelson, E. and Haddad, H., Kluwer Academic Publishers, Boston, USA, 445-452, 2000.

Morin, J., Sharon, D., and Rubin, S.: Rainfall intensities in Israel, Research Report, Hebrew University of Jerusalem, 46-53, 1994.

Pellerin, B. A., Wollheim, W. M., Feng, X. J., and Vorosmarty, C. J.: The application of electrical conductivity as a tracer for hydrograph separation in urban catchments, Hydrol. Process., 22, 1810-1818, 2008.

Piguet, P., Parriaux, A., and Bensimon, M.: The diffuse infiltration of road runoff: an environmental improvement, Sci. Total Environ., 397, 13-23, 2008.

Ragab, R., Bromley, J., Rosier, P., Cooper J. D., and Gash, J. H. C.: Experimental study of water fluxes in a residential area: 1 . Rainfall, roof runoff and evaporation: the effect of slope and aspect, Hydrol. Process., 17, 2409-2422, 2003a.

Ragab, R., Rosier, P., Dixon, A., Bromley, J., and Cooper, J. D.: Experimental study of water fluxes in a residential area: 2. Road infiltration, runoff and evaporation, Hydrol. Process, 17, 24232437, 2003b.

Ramier, D., Berthier, E., and Andrieu, H.: An urban lysimeter to assess runoff losses on asphalt concrete plates, Phys. Chem. Earth., 29, 239-847, 2004.

Ramier, D., Berthier, E., and Andrieu, H.: Study of the water budget of streets: experimentation and modelling, Water Sci. Technol. 54(6-7), 41-48, 2006.

Rutsch, M., Rieckermann, J., and Krebs, P.: Quantification of sewer leakage: a review, Water Sci. Technol., 54(6-7), 135-144, 2006.

Sharon, D. and Kutiel, H.: The distribution of rainfall intensity in Israel, its regional and seasonal variations and its climatological evaluation, J. Climatol, 6(3), 277-291, 1986.

Sharon, D.: Areal patterns of rainfall in a small watershead as affected by wind and meteorological conditions, Symp. Results of Research on Representative and Experimental Basins, Wellington, 1970, Int. Assoc. Sci. Hydrol., 96, 3-11, 1970.

Sharon, D., Margalit, A., and Arazi, A.: The study of rainfall distributions in small watersheds in Israel: From early observations to model simulations, IAHS-AISH, 261, 13-28, 2000.

Smullen, J. T., Shallcross, A. L., and Cave, K. A.: Updating the US nationwide urban runoff quality data base, Water Sci. Technol., 39(12), 9-16, 1999.

Soller, J., Stephenson, J., Olivieri, K., Downing, J., and Olivieri, A. W.: Evaluation of seasonal scale first flush pollutant loading and implications for urban runoff management, J. Environ. Manage., 76, 309-318, 2005. 
Trimble, S. W.: Contribution of Stream Channel Erosion to Sediment Yield from an Urbanizing Watershed, Science, 278, 14421444, 1997.

Trowsdale, S. A. and Lerner D. N.: A modeling approach to determine the origin of urban ground water, J. Contam. Hydrol., 91, 171-183, 2007.

US Army Corps of Engineers: HEC-RAS River Analysis System Hydraulic Reference Manual, US Army Corps of Engineers, Davis, California, p.262, 2001.

US EPA (Environmental Protection Agency): Preliminary data summary of urban storm water best management practices, EPA821-R-99-012, Office of Water, Washington, DC, p.214, 1999.

US EPA (Environmental Protection Agency): National Menu of Best Management Practices for Stormwater Phase II, http: //cfpub.epa.gov/npdes/stormwater/menuofbmps/index.cfm (last access: 8 July 2009) 2002.
US-NRC: Urban Stormwater Management in the United States: http://books.nap.edu/openbook.php?record_id=12465, (last access: 8 July 2009), 2008.

Weinberger, G., Rosenthal, E., Ben-Zvi, A., and Zeitoun, D. G.: The Yarkon-Taninim groundwater basin, Israel hydrogeology: case study and critical review, J. Hydrol., 161, 227-255, 1994.

Wolman, M. G. and Schick, A. P.: Effects of construction on fluvial sediment: urban and suburban areas of Maryland, Water Resour. Res., 3, 451-462, 1967.

Zoppou, C.: Review of urban storm water models, Environ. Modell. Softw., 16(3), 195-231, 2001. 